\section{A ROMAN THIN-CAST BRONZE SAUCEPAN FROM THE DACIAN FORTRESS AT ARDEU (HUNEDOARA COUNTY, ROMANIA) ${ }^{1}$}

\begin{abstract}
The article analyzes a Roman thin-cast bronze saucepan discovered in the Dacian fortress from Ardeu (Hunedoara County, Romania). The authors argue that the object belongs to a small group of similar discoveries which comprises a variant of the thin-cast saucepans belonging to Petrovszky type III. The saucepan was produced between the last two decades of the $1^{\text {st }}$ century $\mathrm{BC}$ and the third decade of the $1^{\text {st }}$ century $\mathrm{AD}$ in a workshop which can be located in the north-eastern part of the Italic Peninsula, probably at Aquileia. This is the first discovery which attests with certainty the existence of the thin-cast saucepans in the north Danubian territory, element which is important in the context of the trade relations developed along the route connecting Aquileia with the Sava Valley and the Danube during the Augustan Age.
\end{abstract}

Keywords: pre-Roman Dacia, Ardeu, trade, imports, Roman bronze vessels.

\section{Silvia Mustață \\ Mureș County Musem, Tîrgu Mureș \\ silvia_mustata@yahoo.com}

\section{Iosif Vasile Ferencz}

Museum of Dacian and Roman Civilisation, Deva fiosifvasile@yahoo.com

\section{Cristian Dima \\ National History Museum of Transylvania, Cluj-Napoca dimav.cristian@yahoo.com}

DOI: http://dx.doi.org/10.14795/j.v1i2.49

ISSN $2360-266 \mathrm{X}$

ISSN-L $2360-266 \mathrm{X}$
$\mathbf{N}$ ewer or older information regarding the Dacian fortress at Ardeu has been constantly presented in the archaeological literature of the last decade ${ }^{2}$. The archaeological site Ardeu - Cetățuie is located on the territory of Ardeu village, commune of Balșa, Hunedoara County (Fig. 1/1) and it comprises the hill with the same name (maximum height from the Black Sea level: $455 \mathrm{~m}$ ), the plateau situated to the east, the foothills, the terraces positioned towards south and the Ardeu Gorges from the south-western part (Fig. 1/2). The hill with steep slopes is surrounded by Ardeu Valley which forms on the northern and western sides a sector of short and picturesque gorges. All the parts composing the site have been inhabited throughout several historical periods ${ }^{3}$; nevertheless, the archaeological information published so far is mostly related to the Dacian land use.

The archaeological research of the site started at the end of the $19^{\text {th }}$ century, under the supervision of Téglás Gábor ${ }^{4}$. Subsequently, the Museum

\footnotetext{
${ }^{1}$ This work was supported by a grant of the Ministry of National Education, CNCS-UEFISCDI, no. PN-II-ID-PCE-2012-4-0618.

${ }^{2}$ FERENCZ/BODÓ 2003; FERENCZ 2003; FERENCZ 2005; FERENCZ 2006; FERENCZ/DIMA 2009; FERENCZ/GURGU-ŢîRDOIU 2009; FERENCZ 2010a; FERENCZ 2010b; FERENCZ 2010c; FERENCZ 2012a; FERENCZ 2012b; FERENCZ 2013a; FERENCZ 2013b; FERENCZ 2013c; BELDIMAN ET ALII 2013a; BELDIMAN ET ALII 2013b; BELDIMAN ET ALII 2013c; FERENCZ/ FLOREA 2013

${ }^{3}$ See: FERENCZ/ROMAN 2010, 173.

${ }^{4}$ TÉGLAS 1885, 299-307; TÉGLAS 1888, 134-138
} 
from Deva together with the National History Museum of Romania from Bucharest undertook a small scale excavation in the area as a result of disturbances caused by the opening of a stone quarry which led to the identification of several metallic artefacts ${ }^{5}$. Starting with 2001 the Museum of Dacian and Roman Civilisation from Deva resumed the field research from Ardeu together with various partners: the " 1 st of December 1918" University (Alba Iulia), the National History Museum of Transylvania (Cluj-Napoca), and the Corvin Castle Museum (Hunedoara) ${ }^{6}$.

In 1971 the museum from Deva acquired a series of metallic objects discovered on the Cetățuie Hill by three employees of the Limestone Quarry from Ardeu. The saucepan analyzed here was discovered among the shrubs covering the slopes of the hill by Simion Pârva from the village of Balșa7.

The saucepan ${ }^{8}$ (Fig. 2/1-2, 3/1-3, 4/1-2) is preserved in the collections of the Museum of Dacian and Roman Civilisation from Deva and it is registered with the inventory number: 23382. As mentioned before, it is a stray find, discovered on the eastern slope of the hill, situation which hinders any kind of supposition related to the context in which it might have been used. The object, made of copper based alloy and displaying an irregular patina, ranging from light to dark brown with light to dark green areas, is in a relatively good state of preservation, although it presents parts in which the oxidation process is still active. It is fragmentary, since only the handle (with the end partially broken), part of the rim, and part of the body are preserved, and its dimensions are the following: Diameter (rim): $110 \mathrm{~mm}$; maximum Height: $41 \mathrm{~mm}$; Thickness (body): 0.5-0.8 mm; Length (handle): $157 \mathrm{~mm}$; Width (handle): 17-22 mm; Thickness (handle): 3-4.5 mm; Weight: $115 \mathrm{~g}$. The saucepan was produced from two pieces of metal: the rim and the handle were cast separately and attached subsequently to the body made of a thin cast shape which was, very probably, pressed on a model with the help of the lathe. The area of the joining is visible only on the inner side of the vessel, under the rim, together with other traces of hammering which were not dimmed during the finishing process (Fig. 4/1). From a morphological viewpoint, the saucepan displays a horizontal rim, slightly everted towards the exterior, with a triangular profile. The rim is decorated with a band of ovolo alternated with vertical incisions followed towards the exterior by a band of small, incised circles. The sides of the body are slightly convex and much damaged in the inferior part. The body is decorated under the rim with three incised parallel grooves. The handle of the vessel is not perfectly horizontal, but easily elevated, especially towards its end. It displays a slenderer central part and it ends with a ring, partially preserved, and separated from the rest of the handle by a narrower part, marked with

\section{${ }^{5}$ NEMOIANU/ANDRIŢOIU 1975}

${ }^{6}$ PESCARU ET ALII 2002; FERENCZ ET ALII 2003; FERENCZ ET ALII 2004; FERENCZ ET ALII 2005; FERENCZ ET ALII 2010; FERENCZ ET ALII 2011.

${ }^{7}$ In the spring of 2014 Iosif Vasile Ferencz had the opportunity of discussing with Simion Pârva who is now more than 80 years old. Even if he does not remember the exact location where he discovered the objects bought by the museum, he indicated without any hesitation that they were all found among the shrubs covering the eastern slope of the hill (see Fig. 1/2) and that they were not found together.

${ }^{8}$ For a first publication of the object see: GHEORGHIU 2005, 168, 488, Fig. 214. parallel incised lines. The decoration of the handle consists of stylized snakes with the body arranged in the shape of a spiral forming a vegetal motif, each of them facing right or left in a successive manner (Fig. 2/1, 3/1). Above each animal head, another depiction can be observed, representing, this time, only a head of snake. This detail is visible only for the first four spirals. The body of the snakes is marked with punched circles. Other elements of the decoration, hardly visible, are represented by the oblique lines with circles inside flanking the exterior of the spirals, in the area where they join, and the band of incised circles, visible only on the right side, towards the rim. In general, the decoration was made in a simple manner, by marking with incisions only the exterior contours. The lines are now worn-out and hardly visible, situation which can be explained through the intensive and/ or prolonged usage of the object in ancient times. Very likely, the spirals covered, initially, the whole surface of the handle. Currently, only parts of the first five and of the seventh one are visible. The saucepan preserves at the end of the handle the craftsman's stamp which can be observed on a length of $20 \mathrm{~mm}$ and on a width of 4.2-4.8 mm. Because of oxidation and, again, of the worn-out lines, the stamp is almost impossible to read. One can suggest, with caution, the presence of the following letters: CNPO[...]SR? (Fig. 4/2).

From a typological point of view, the saucepan ${ }^{9}$ belongs to a group of bronze vessels known in the archaeological literature as: Blechkasserollen, corresponding to Radnóti types $5-10^{10}$, to Eggers types $134-136^{11}$, and to Petrovszky types III, 1-4 ${ }^{12}$. The term Blechkasserollen is accepted nowadays as

${ }^{9}$ The terminology used to denominate the variant of the type to which the vessel from Ardeu belongs is not well defined in the literature. The vessels displaying similar characteristics have been published under different names, e g.: mestola (Collection of Profane Museum of Vatican (Italy): RADNÓTI 1937, 55-57, Tav. III/1), Blechkasserolle (Vrhnika (Solvenia): RADNÓTI 1938, 38, Taf. II/9, XVII/30; BREŠČAK 1982, 42, no. 17, T. 2/17; PETROVSZKY 1993, 299 (S.13.01), Taf. 26/S.13.01), dipper (Collections of Rijksmuseum G. M. Kam, Nijmegen (Holland): DEN BOESTERD 1956, XXI-XXII, 17, no. 46, Pl. III/46), casserole légère, à paroi plus mince (Saône River (France): BARATTE ET ALII 1984, 60, 67, no. 85, Pl. XXXI/85), attingitoio (Viadana (Italy): BOLLA 1986, 196-198, no. 2, Fig. 4-5). However, the morphological features of the objects which display the highest degree of similarity with the Ardeu vessel (from the Collection of the Profane Museum of Vatican, Saône River, and Viadana) are typical for Blechkasserollen: the shape of the body with slightly convex walls (similar to Bolla type A and B: BOLLA 1986, 202, Fig.8/A, B), the presence of a base which is turned on the lathe in some cases (see the vessel from Saône River), and a handle - ending in a ring divided from the rest of the handle- which does not exceed in length 1.5 of the rim diameter. These elements determined us to use the term saucepan, and not dipper, when describing the bronze vessel from Ardeu and to analyze it accordingly. Likewise, type V from M. Bolla's typology including the saucepan from Viadana corresponds to variant 3 of type III in R. Petrovsky's typology (see: PETROVSZKY 1993, 39). The only object known to us presenting a different morphology, produced, very probably, in the same workshop, is the dipper/ladle with spout discovered in the banks of Saône River, at Saint-Germain-du-Plain (France): the body and base are rounded and the handle measures in length more than three times the value of the rim diameter (see: NEMETH 1993, 51-52, no. 49; BONNAMOUR 2000, 15, 127, no. 129). Following slightly different proportions, the same goes, very probably, for the dipper discovered at Pompeii (Italy), in Casa dei capitelli figurati (WILLERS 1907, 71, Abb. 41/7-7A), included by M. Bolla in the same type with the Viadana vessel (BOLLA 1986, 205; see also TASSINARI 1993, I: 162, II: 161, K 2491).

${ }^{10}$ RADNÓTI 1938, 25-39, Taf. II/5-9, III/10.

${ }^{11}$ EGGERS 1951, 172, Beilage 58: bronzene Blechkasserollen (Typ 134-136), Taf. 12/134-136.

${ }^{12}$ PETROVSZKY 1993, 36-39, Taf. 1/III, 1-4b. 
a convention in the archaeological literature, even if it does not designate the technology used for manufacturing the saucepans belonging to the group. The main characteristic is represented by the very thin walls, despite the fact that the vessels were never produced from bronze sheet, but from a cast shape which was subsequently pressed on a model and finished on the lathe ${ }^{13}$.

For long the scholars did not make a clear distinction between the thin-cast saucepans and the ones with convex body and handle ending in a loop with swan's heads belonging to Eggers types $131-132^{14}$. In A. Radnóti's opinion the latter were cast and produced in the workshops from Capua, while the thin-cast saucepans represent bronze-sheet imitations of the products from Campania, made in the north Italic workshops, probably at Aquileia ${ }^{15}$. Subsequently, M. Bolla's attempt of classifying both groups based on the shape of the body and the decoration of the handle proved that there is no clear connection between these elements ${ }^{16}$. The first who clarified the technological aspects and drew a clear distinction between the two types was R. Petrovszky. As part of the typology of the Roman bronze vessels with craftsman's stamp, the author classified the saucepans with swan's heads produced in Campania in type II (Kasserollen mit Schwanenkopfbügel $)^{17}$ and the thin-cast saucepans in type III (Blechkasserollen) ${ }^{18}$.

The discoveries of thin-cast saucepans are numerous in Northern Italy, Slovenia, Bohemia, Gaul, and the Rhine area. Based on the dates offered by the contexts of the discoveries and on the names attested by the craftsman's stamps, R. Petrovszky sets the production of the type in north-eastern Italy, at Aquileia, between the last two decades of the $1^{\text {st }}$ century $\mathrm{BC}$ and the third decade of the $1^{\text {st }}$ century $\mathrm{AD}^{19}$. The presence in small number of some variants of the type between the finds from Pompeii determined J. Kunow to suggest a production period lasting till the last quarter of the $1^{\text {st }}$ century $\mathrm{AD}^{20}$. Such a hypothesis is unlikely and the thin-cast saucepans from Pompeii should be interpreted as objects used for a long period of time ${ }^{21}$

It is not easy to integrate the saucepan from Ardeu in the variants of the type which have been defined so far. Such an attempt is made harder by the poor publication of at least part of the finds or by the state of preservation of others. There are more elements which need to be considered in this respect: the horizontal rim decorated with a band of ovolo, the slightly convex walls, and the decorated handle ending in a loop separated by a narrow area. Taking these into consideration, the vessels displaying the same characteristics as the saucepan from Ardeu are not numerous. The best parallels are represented by the saucepan from the assembly of bronze vessels dated during the Augustan age and

\footnotetext{
13 BOLLA 1986, 199; FLÜGEL 1993, 60, note 44; PETROVSZKY 1993, 30, 36; KOSTER 1997, 56, no. 65.

${ }^{14}$ EGGERS 1951, 171-172, Beilage 57: Bronzekasserollen mit Schwanenkopfbügel (Typ 131-133), Taf. 12/131-32.

${ }^{15}$ RADNÓTI 1938, 19-39; KUNOW 1983, 62-63.

${ }^{16}$ BOLLA 1986, 199-207.

${ }^{17}$ PETROVSZKY 1993, 30-35, Taf. 1/II, 1-3.

${ }^{18}$ PETROVSZKY 1993, 36-39, Taf. 1/III, 1-4.

${ }_{19}$ PETROVSZKY 1993, 36-39.

${ }^{20}$ KUNOW 1983, 25.

${ }^{21}$ PETROVSZKY 1993, 38; KOSTER 1997, 57
}

discovered at Viadana (Italy) in the $19^{\text {th }}$ century ${ }^{22}$, another one preserved in the Collections of the Profane Museum of Vatican (Italy) ${ }^{23}$ and a saucepan discovered in the Saône River (France) ${ }^{24}$. The band of ovolo is characteristic for the objects from Viadana and Vatican, the shape of the body is similar in all three cases (with a height varying from 55 to $59 \mathrm{~mm}$ ), and all the handles are decorated with incisions: rows of hatches and ovolo near the rim (Viadana), a complex interposed decoration in the shape of a "hair braid" 25 , positioned on half of the handle, near the rim and rows of small circles along the edges (Vatican), and pouched circles forming three floral motifs, flanked along the edges of the handle by a row of small circles (Saône). The handles end with a loop corresponding to Bolla type V in two cases (Viadana, Saône) and with one of Bolla type IV in one (Vatican) ${ }^{26}$. Because of the strong similarities, one can also mention here the dipper with spout discovered in the bank of the Saône River, near Saint-Germain-du-Plain (France) ${ }^{27}$ which has a rim decorated with ovolo, a handle decorated with a complex incised vegetal decoration, ending in a loop similar to the one of the saucepan from Ardeu. The band of ovolo on the rim and the end of the handle typical for Bolla type $V$ appear on a fragmentary saucepan from the Collections of Rijksmuseum G. M. Kam, Nijmegen (Holland) ${ }^{28}$ and the same decoration of the handle end can be observed on a thin-cast saucepan with concave walls, bearing the stamp STAG/Staglius Philoca (lus ?), discovered at Vrhnika (Solvenia) ${ }^{29}$.

Summarizing the above-mentioned, the saucepans from Ardeu, River Saône, Viadana, and the Collections of the Profane Museum of Vatican represent a distinct variant of the thin-cast saucepans, characterized by a horizontal rim, decorated with a band of ovolo in most of the cases, a small body with slightly convex walls, a flat base, sometimes turned on the lathe, and a handle belonging to Bolla types IV or $\mathrm{V}$, provided with a rich incised decoration. Except for the saucepan from Viadana the objects are stray finds. Because of that there is no possibility of narrowing down the production period. But they were certainly produced between the last two decades of the $1^{\text {st }}$ century $\mathrm{BC}$ and the third decade of the $1^{\text {st }}$ century $A D$, as the rest of the thin-cast saucepans. The saucepan from Ardeu is the only discovery from the group bearing a craftsman's stamp. As long as the letters proposed above have a high degree of uncertainty, due to the preservation state, the attempt of proposing a reading would be too speculative.

${ }^{22}$ BOLLA 1986, 196-198, nr. 2, Fig. 4-5; BOLLA 1991, 151-152, Fig. 5/1. ${ }^{23}$ RADNÓTI 1937, 55-57, Tav. III/1; BOLLA 1986, 205, tipo IV, note 36 (with the bibliography).

${ }^{24}$ BARATTE ET ALII 1984, 60, 67, no. 85, Pl. XXXI/85.

${ }^{25}$ The low quality of the illustration does not allow a good observation of the depiction: ...sul mezzo è inciso, in direzione della lunghezza, un ornamento intrecciato, somigliante ad una treccia di capelli, di cui si vede particolarmente bene l'estremità. La treccia presenta l'incrocio di due linee ondulate, si restringe verso la metà del manico, quindi improvvisamnete termina. (RADNÓTI 1937, 55).

${ }^{26}$ BOLLA 1986, 201, Fig. 7/IV-V.

${ }^{27}$ NEMETH 1993, 51-52, no. 49; BONNAMOUR 2000, 15, 127, no. 129.

${ }^{28}$ DEN BOESTERD 1956, XXI-XXII, 17, no. 46, Pl. III/46; BOLLA 1986 205 , note 37

${ }^{29}$ RADNÓTI 1938, 38, Taf. II/9, XVII/30; BREŠČAK 1982, 42, no. 17, T. 2/17; BOLLA 1986, 205, note 37; PETROVSZKY 1993, 299 (S.13.01), Taf. 26/S.13.01. 
The presence of a thin-cast saucepan at Ardeu is of high importance in the context of the discussion regarding the north Italic imports which arrived in pre-Roman Dacia during the Augustan period, after the establishmnet of the trade route connecting the north-eastern part of the Italic Peninsula with the Sava River and the Danube ${ }^{30}$. This is the first object which attests with certainty the existence of the type in this territory ${ }^{31}$, especially as long as the two handles, one belonging to a thin-cast saucepan Petrovszky III, 1 and the other to a dipper/strainer Petrovszky X, 2, acquired from Cuzdrioara and preserved in the Collection of the National History Museum of Transylvania, Cluj-Napoca do not have an exact place of discovery ${ }^{32}$.

Even if the context of the discovery is not known, the saucepan from Ardeu was definitely used for a long period of time, fact indicated by the worn-out lines of the handle decoration. The object, as the other thin-cast saucepans, was part of the drinking service and it was used for mixing the wine before serving ${ }^{33}$.

\section{References}

\section{BARATTE ET ALII 1984}

Baratte, Fr./ Bonamour, L./ Guillaumet, J.-P./ Tassinari, S., Vases antiques de métal au Musée de Chalon-sur-Saône. Revue Archéologique de L'Est et du Centre-Est Suppl. $5^{\text {ème }}$ (Dijon).

\section{BELDIMAN ET ALII 2013a}

Beldiman, C./ Ferencz, I. V./ Sztancs, D. M., Dacian osseous materials industry. Case study: the artefacts from hillfort of Ardeu, Hunedoara County. In Stavilă, E./ Micle, D./ Cîntar, A./ Floca, C./ Forţiu, S. (eds.), Interdisciplinaritate in arheologie și istorie. In Memoriam Liviu Măruia, Arheovest I/1, 745-772 (Szeged: JATEPress Kiadó).

BELDIMAN ET ALII 2013b

Beldiman, C./ Ferencz, I. V./ Sztancs, D. M., Dacian osseous materials artefacts discovered at Ardeu-"Cetățuie", Hunedoara County. Decorated red deer antler plate. In Ferencz, I. V./ Rișcuța, C./ Tutilă, O. (eds.), Archaeological small finds and their significance. Proceedings of the symposion: Costume as an identity expression, 113-129 (Cluj-Napoca: Mega Publishing House).

BELDIMAN ET ALII 2013c

Beldiman, C./ Ferencz, I. V./ Sztancs, D. M., Data about the osseous materials artefacts from Dacian hillfort of Ardeu, Hunedoara county, Romania. In Schuster, C./ Cîrstina, O./ Cosac, M./ Murătoreanu, G. (eds.), The Thracians and their neighbours in the bronze and iron ages. Settlements, fortresses, artifacts. Proceedings of the $12^{\text {th }}$ International Congress of Thracology, vol. 1 (Târgoviște: Ed. Cetatea de Scaun).

BOLLA 1986

Bolla, M., 1. Casseruola, attingitoio e situla da Viadana. In Bolla, M./ Castoldi, M./ Terenziani, L., Recipienti in bronzo d'età romana in Lombardia. Scritti in ricordo di Graziella Massari Gaballo e Umberto Tocchetti Pollini, 195-209 (Milano).

\footnotetext{
${ }^{30}$ For a detailed discussion on the subject see: RUSTOIU 2005, 79-84.

${ }^{31}$ The identification of the saucepan discovered in the Dacian dava from Brad (Romania) with a variant of the type is not certain for the moment. Even if the context of the discovery is placed in the $1^{\text {st }}$ century $B C$, the quality of the illustration is poor, the vessel was fragmentary and reconstructed in the drawing, thus it needs a detailed examination (for the saucepan form Brad see: URSACHI 1995, 132-133, 406, Pl. 17/3).

32 MUSTAȚ̆ 2013, 125-128, no. 1, 139-140, no. 16, Pl. XIII/1, XVIII/16, LVI/1, LXII/16a-b.

${ }^{33}$ PETROVSZKY 1993, 38.
}

\section{BOLLA 1991}

Bolla, M., Considerazioni sulla funzione dei vasi in bronzo tardorepublicani in Italia settentrionale. In . Feugère, M./ Rolley, $\mathrm{Cl}$. (eds.), La vaissele tardo-républicaine en bronze, Actes de la table-ronde CNSR organisée à Lattes du 26 au 28 avril 1990 par l'UPR 290 (Lattes) et le GDR 125 (Dijon). Centre de recherches sur les techniques gréco-romaines 13 (Dijon), 143-153.

\section{BONNAMOUR 2000}

Bonnamour, L., Archéologie de la Saône. 150 ans de recherches. Le fleuve gardien de la mémoire (Paris: Éditions Errance).

\section{BREŠČAK 1982}

Breščak, D., Antično bronasto posodje Slovenije (Roman bronze vessels in Slovenia). Situla 22/1, 1-59, T. 1-27.

DEN BOESTERD 1956

Den Boesterd, M. H. P., The Bronze Vessels in the Rijksmuseum G. M. Kam at Nijmegen. Description of the Collections in the Rijksmuseum G. M. Kam at Nijmegen V (Leiden: Drukkerij G. J. Thieme).

\section{EGGERS 1951}

Eggers, H. J., Die römische Import im freien Germanien. Atlas der Urgeschhichte, I-II (Hamburg).

\section{FERENCZ 2003}

Ferencz, I. V., Două fibule deteriorate descoperite la Ardeu (com. Balșa, jud. Hunedoara). Sargetia 31, 99-110.

\section{FERENCZ 2005}

Ferencz, I. V., On a Roman lamp discovered in the Dacian fortress from Ardeu, Hunedoara County, Romania. In Gaiu, C./ Găzdac, C. (eds), Fontes Historiae. Studia in honorem Demetrii Protase, 371-377 (Bistriţa - Cluj-Napoca: Ed. Accent).

\section{FERENCZ 2006}

Ferencz, I. V., Două fibule cu resort bilateral mare și coarda înfășurată de arc, provenind din așezarea dacică de la Ardeu, com. Balșa, jud. Hunedoara. BAM I/1, 67-76.

FERENCZ 2010a

Ferencz, I. V., O ferecătură de casetă descoperită la Ardeu. Terra Sebus 2, 225-233.

\section{FERENCZ 2010b}

Ferencz, I. V., Obiecte de os și corn descoperite la Ardeu (jud Hunedoara). In Glodariu, I./ Gheorghiu, G., Studii de Istorie și Arheologie. Omagiu cercetătorului dr. Eugen Iaroslavschi, 79-90 (Cluj-Napoca: Ed. Argonaut).

FERENCZ 2010c

Ferencz, I. V., Chei romane descoperite la Ardeu. In Pop, H./ Bejinariu, I./ Băcueț-Crișan, S./ Băcueț-Crișan, D. (eds.), Identități culturale locale și regionale în context european. Studii de arheologie și antropologie istorică. In Memoriam Alexandri V. Matei, 287-292 (Cluj-Napoca: Mega Publishing House).

\section{FERENCZ 2012a}

Ferencz, I. V., Aproape un secol de uitare. Unele repere istoriografice privind cetatea dacică de la Ardeu. In Drăgan, C./ Barna, C. (eds.), Studii de istorie a Transilvaniei. Volum dedicat istoricului Ioachim Lazăr la 70 de ani, 70-84 (Cluj-Napoca - Deva: Ed. Argonaut).

FERENCZ 2012b

Ferencz, I. V., Late Iron Age brooch which enamelled plaque from Ardeu. Marisia 32, 79-84.

FERENCZ 2013a

Ferencz, I. V., O pafta din fier placată cu bronz descoperită la Ardeu, jud. Hunedoara. In Stavilă, E./ Micle, D./ Cîntar, A./ Floca, C./ Forţiu, S. (eds.), Interdisciplinaritate în arheologie și istorie. In Memoriam Liviu Măruia, Arheovest I/1, 215-224 (Szeged: JATEPress Kiadó).

FERENCZ 2013b

Ferencz, I. V., The Dacian painted pottery discovered at Ardeu, Hunedoara County, Romania. Sargetia S.N. 4 (XL), 165-176. 


\section{FERENCZ 2013c}

Ferencz, I. V., Dacian objects from Ardeu in the collection of the MNIR. Ziridava 27, 135-144.

FERENCZ/BODÓ 2002

Ferencz, I. V./ Bodó, C., Über eine in Ardeu (Gem. Balșa, Kr. Hunedoara, Rumänien) entdeckte unvollendete Fibel. Instrumentum 18, 20-21.

FERENCZ/DIMA 2009

Ferencz, I. V./ Dima, C., Piese de armament dacice descoperite la Ardeu (jud Hunedoara). SUBB-Historia 54/1-2, 18-34.

FERENCZ/GURGU-ŢÎRDOIU 2009

Ferencz, I. V./ Gurgu-Tुîrdoiu, D., Parts of a sica discovered at Ardeu. Corviniana XIII, 159-16.

FERENCZ/ROMAN 2010

Ferencz, I. V./ Roman, C. C., The Dacian fortress from Ardeu research directions. ActaTS 9, 173-184.

FERENCZ/DIMA 2013

Ferencz, I. V./ Dima, C., Despre un stylus descoperit la Ardeu, jud Hunedoara. Drobeta 23, 113-120.

FERENCZ/FLOREA 2013

Ferencz, I. V./ Florea, M., A small silver spiral from Ardeu Romania. Terra Sebus 5, 227-236.

FERENCZ ET ALII 2003

Ferencz, I. V./ Căstăian, M. C./ Bodó, C./ Popa, C. I./ Andrei, Șt./ Stăncescu, R., Ardeu, com Balșa, jud. Hunedoara, punct Cetăţeaua. In Angelescu, M. V./ Borș, C./ Vasilescu, F./ Bem, C./ Tănăsescu, B./ Udrea, F./ Vasilescu, T. (eds.), CCA. Campania 2002, 40-42 (București).

FERENCZ ET ALII 2004

Ferencz, I. V./ Căstăian, M. C./ Bodó, C./ Popa, C. I./ Andrei, Șt./ Stăncescu, R., Ardeu, com Balșa, jud. Hunedoara, punct Cetăţuie (Cetăţeaua). In Angelescu, M. V./ Oberländer-Târnoveanu, I./ Vasilescu, F. (eds.), CCA. Campania 2003, 43-45.

FERENCZ ET ALII 2005

Ferencz, I. V./ Bodó, C./ Căstăian, M. C., Ardeu, com Balșa, jud. Hunedoara, punct Cetăţuie. In Angelescu, M. V./ OberländerTârnoveanu, I./ Vasilescu, F. (eds.), CCA. Campania 2004, 56-57 (București).

FERENCZ ET ALII 2010

Ferencz, I. V./ Roman, C. C./ Căstăian, M. C./ Dima, C./ Popa, C. I., Ardeu (com. Balșa, jud. Hunedoara). In Angelescu, M. V./ Bem, C./ Oberländer-Târnoveanu, I./ Vasilescu, F. (eds.), CCA. Campania 2009, 28-29 (București).

FERENCZ ET ALII 2011

Ferencz, I. V./ Roman, C. C., Căstăian, M. C./ Dima, C./ Popa, C. I., Ardeu (com. Balșa, jud. Hunedoara). In Angelescu, M. V./ Bem, C./ Oberländer-Târnoveanu, I./ Vasilescu, F. (eds.), CCA, Campania 2010, 28-29 (Sibiu).

FLÜGEL 1993

Flügel, Ch., Die Bronzegefüsse von Kemptem-Cambodunum. Cambodunumforschungen V, Materialhefte zur Bayerischen Vorgeschichte 63, 53-114, Taf. 24-35 (Kallmünz: Verlag Michael Lassleben).

GHEORGHIU 2005

Gheorghiu, G., Dacii pe cursul mijlociu al Mureșului: sfârșitul sec. II a. Chr. - inceputul sec. II p. Chr. (Cluj-Napoca: Mega Publishing House).

KOSTER 1997

Koster, A., The bronze vessels 2. Acquisitions 1954-1996 (including vessels of pewter and iron). Description of the Collections in the Rijksmuseum G.M. Kam at Nijmegen XIII (Nijmegen: Provincie Gelderland).

KUNOW 1983

J. Kunow, Der römische Import in der Germania libera bis zu den Markomannenkriegen. Studien zu Bronze- und Glasgefäßen.
Göttinger Schriften zür Vor- und Frühgeschichte 21 (Neumünster: Verlag Karl Wachholtz).

MUSTAȚ̆ 2013

Mustață, S., Vasele de bronz romane din Dacia Porolissensis. $\mathrm{PhD}$ thesis (Cluj-Napoca).

\section{NEMETH 1993}

Nemeth, O., Vases antiques de metal trouvés dans la moyenne vallée de la Saône, + Illustrations. Mémoire de Maitrise d’Achéologie, Université des Lettres et Sciences Humaines de Dijon (sous la direction de Claude Rolley).

NEMOIANU/ANDRIŢOIU 1975

Nemoianu, L./ Andriţoiu, I., Sondajul arheologic de la Ardeu, com. Balșa, jud. Hunedoara. CercArh 1, 181-190.

PESCARU ET ALII 2002

Pescaru, A./ Bodó, C./ Căstăian, M. C./ Ferencz, I. V., Ardeu, com Balșa, jud. Hunedoara, punct Cetăţeaua. In Angelescu, M. V./ Bem, C./ Oberländer-Târnoveanu, I./ Vasilescu, F. (eds.), CCA. Campania 2001, 41-43 (București).

\section{PETROVSZKY 1993}

Petrovszky, R., Studien zu römischen Bronzegefäßen mit Meisterstempeln. Kölner Studien zur Archäologie der Römischen Provinzen 1 (Buch am Erlbach: Verlag Marie L. Leidorf).

\section{RADNÓTI 1937}

Radnóti, A., Vasi di bronzo romani nel Museo Profano del Vaticano. Biblioteca dell'Accademia d'Ungheria di Roma 4 (Roma).

RADNÓTI 1938

Radnóti, A., Die römische Bronzegefässe von Pannonien. DissPann II/6 (Budapest).

\section{RUSTOIU 2005}

Rustoiu, A., Dacia și Italia în sec. I a. Chr. Comerțul cu vase de bronz în perioada republicană târzie (studiu preliminar)/Dacia and Italia in the 1st century BC. The trade with bronze vessels during the Late Republican Period (preliminary study). In Cosma, C./ Rustoiu, A. (eds.), Comerț și civilizație. Transilvania in contextul schimburilor comerciale și culturale în Antichitatel Trade and civilisation. Transylvania in the frame of trade and cultural exchanges in Antiquity. Interferențe etnice și culturale în mileniile I a. Chr. - I p. Chr. VII (Cluj-Napoca: Mega Publishing House).

\section{TASSINARI 1993}

Tassinari, S., Il vasellame bronzeo di Pompei. Ministero per i beni culturali ed ambientali, Soprintendenza Archeologica di Pompei, Cataloghi 5 (Roma: L’Erma di Bretschneider).

TÉGLAS 1885

Téglas, G., Emlékek és leletek. Az erdőfalvi barlangok. AÉrt 5, 299-307.

\section{TÉGLAS 1888}

Téglas, G., Újabb barlangok az erdélyrészi Érczhegység övéből. Matematikai és természettudományi Közlemények XIII, 134 - 138 (Budapest).

\section{URSACHI 1995}

Ursachi, V., Zargidava. Cetatea dacică de la Brad. Bibliotheca Thracologica X (București).

WILLERS 1907

Willers, H., Neue Untersuchungen über die römische Bronzeindustrie von Capua und von Niedergermanien besonderes auf die Funde aus Deutschland und dem Norden hin (Hannover Leipzig: Verlag Hahnsche Buchhandlung). 


\section{ABBREVIATIONS}

ActaTS

BAM

CercArh

CCA

Corviniana

DissPann

Drobeta

Acta Terrae Septemcastrensis (Sibiu).

Brukenthal. Acta Musei (Sibiu).

Cercetări Arheologice. Muzeul Național de Istorie a României (București).

Cronica Cercetărilor Arheologice din România.

Corviniana. Acta Musei Corviniensis (Hunedoara).

Dissertationes Pannonicae ex Instituto

Numismatico et Archaeologico Universitatis de Petro Pázmány nominatae Budapestinensis provenientes (Budapest).

$\begin{array}{ll} & \text { (Drobeta-Turnu Severin). } \\ \text { Instrumentum Instrumentum. Bulletin du Groupe de travail }\end{array}$ européen sur l'artisanat et les productions manufacturées dans l'Antiquité à l'époque moderne (Montagnac).

Marisia Marisia. Studii și Materiale. Arheologie (Târgu Mureș).

Sargetia (S. N.) Sargetia. Acta Musei Devensis (Serie Nouă) (Deva).

Situla Situla. Razprave Narodnega Muzeja v Ljubljani - Dissertationes Musei Nationalis Labacensis (Ljubljana).

SUBB-Historia Studia Universitatis Babeș-Bolyai-Historia (Cluj-Napoca).

Terra Sebus Terra Sebus. Acta Musei Sabesiensis (Sebeș).

Ziridava Ziridava. Studia Archaeologica (Arad). 


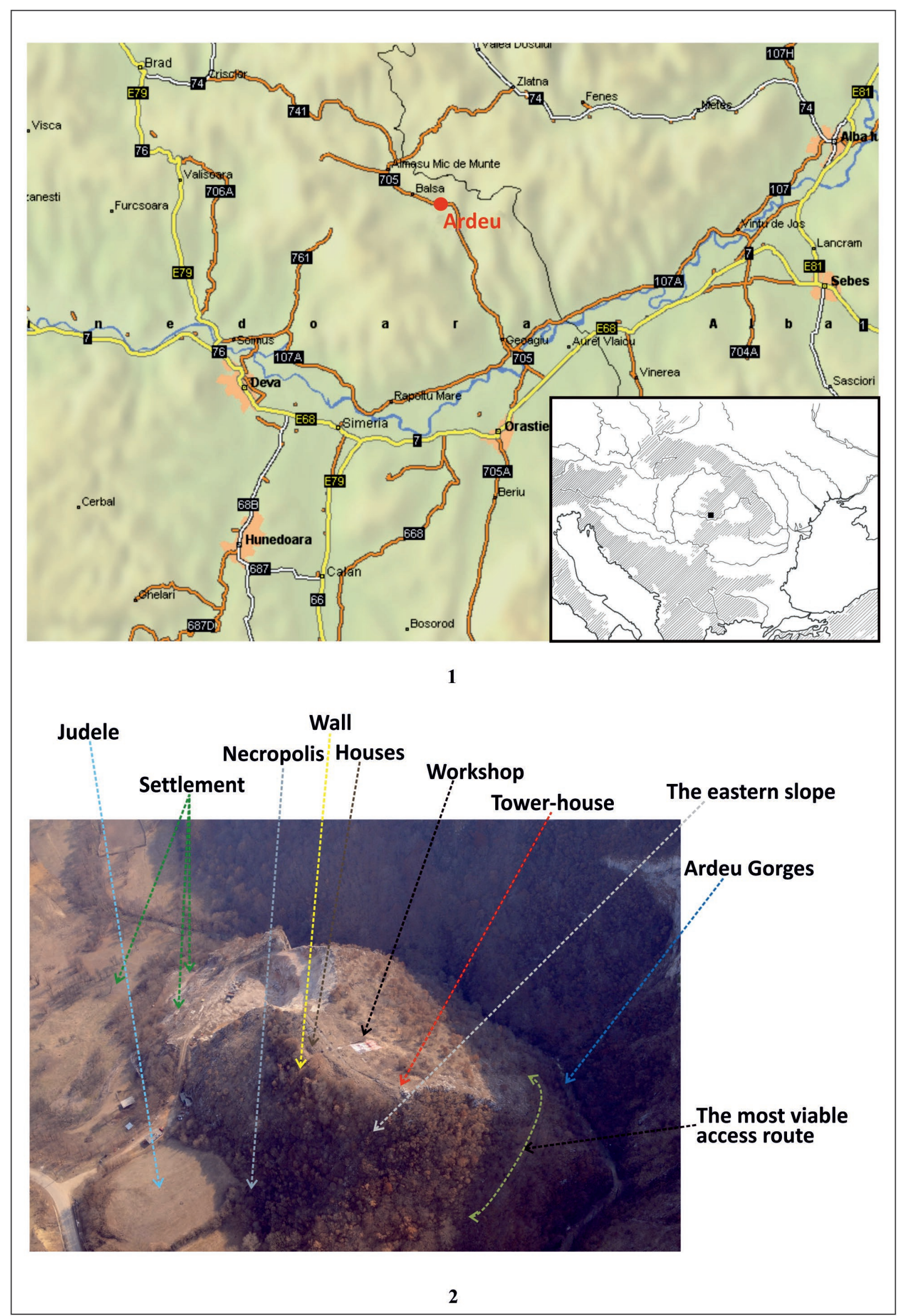

Fig. 1. 1. The location of Ardeu village (after FERENCZ 2010a);

2. The main components of the site (aerial view by Zoltán Czajlik, may 2012). 


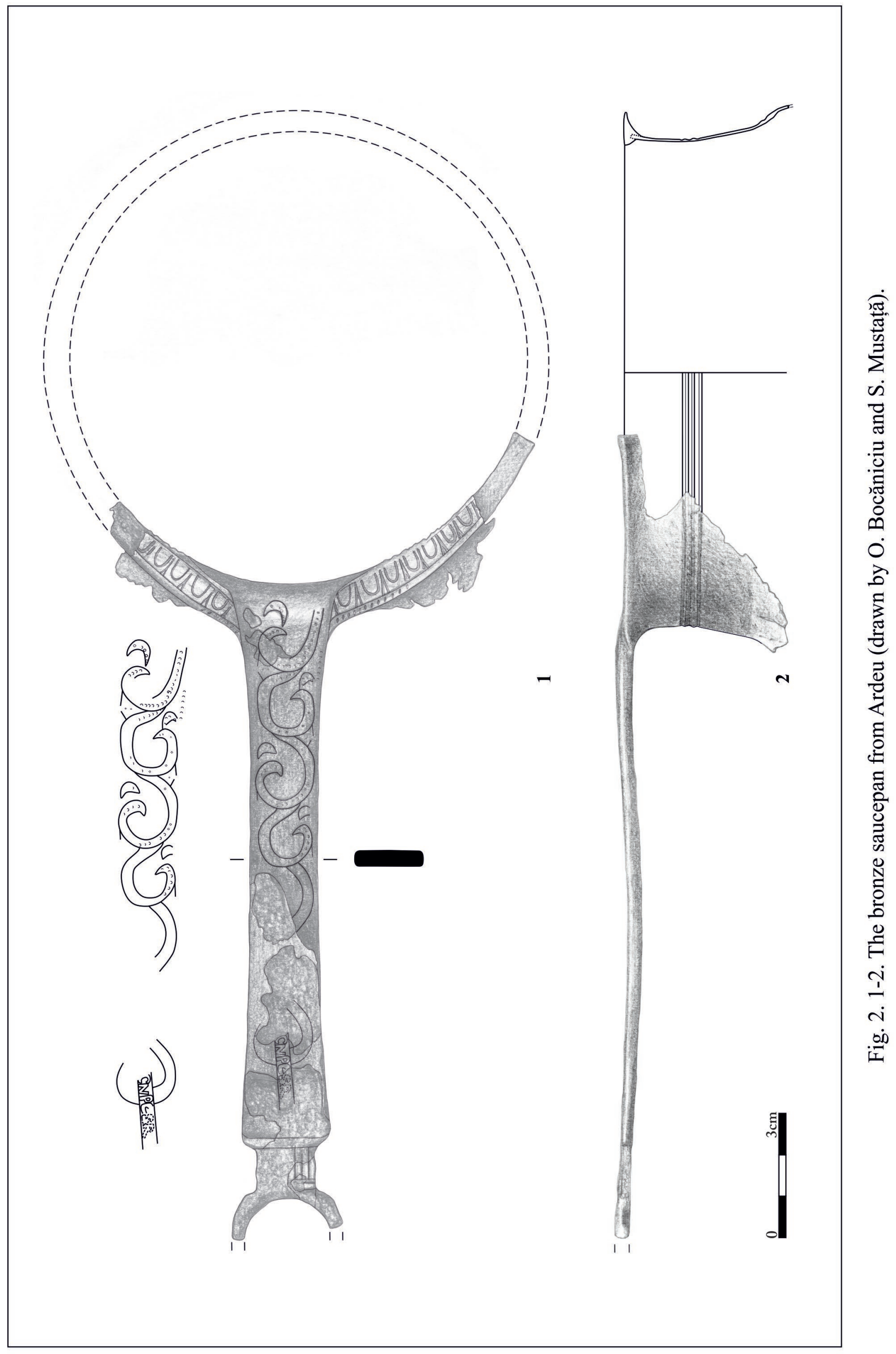




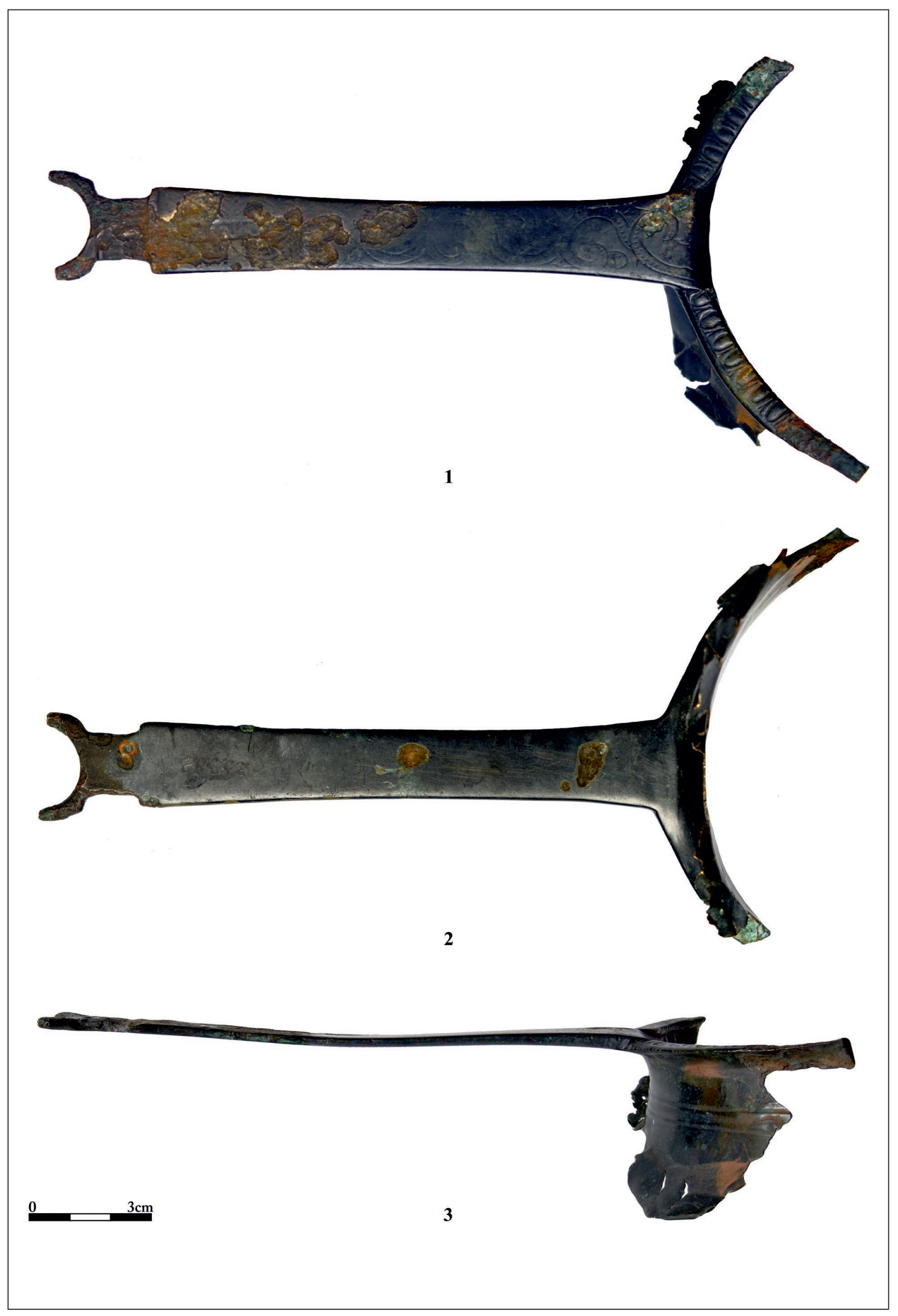

Fig. 3. 1-3. The bronze saucepan from Ardeu (photos made by: 1-2: S. Mustață; 3: S. Odenie). 

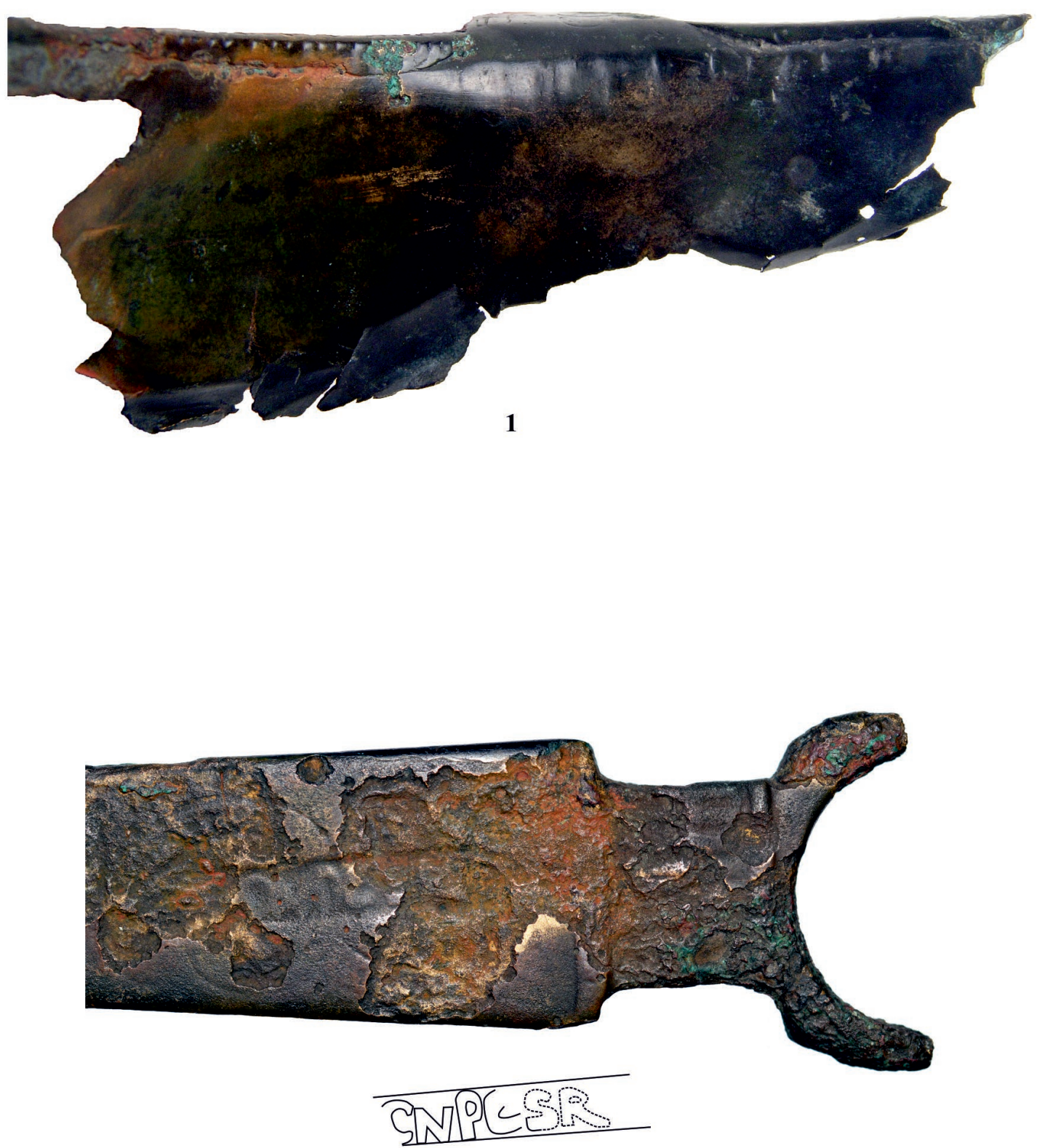

2

Fig. 4. 1-2. The bronze saucepan from Ardeu. Details. 1. The inner side (no scale; photo made by S. Odenie); 2. The stamp (photo and drawing made by S. Mustață). 